CIENCIA Y SOCIEDAD

Volumen XVI, Número 3

Julio - Septiembre 1991

\title{
DOS NOVELAS DIDACTICAS DE JAIME COLSON
}

\section{Giovanni Di Pietro*}

Aparentemente la suerte no ha sido buena con Jaime Colson. Casi olvidado como pintor en su país, es, además, totalmente desconocido como escritor. Como escritor, sí, porque Jaime Colson, para quien se diera la molestia de investigar, tiene a su crédito la publicación de dos novelas. Existe también, según un escrito aparecido en "coloquio"," una novela inédita, Concho Primo, por lo que sospechamos que hay otras obras. Pero, conociendo el descuido en que se encuentra el estudio de la novelística dominicana contemporánea, este estado de cosas no nos debería sorprender. En otra ocasión hemos hablado de la frecuencia con que los novelistas dominicanos son objeto de indiferencia por parte de los estudiosos en materia. Jaime Colson no es, pues, el único caso; mejores novelistas han padecido de esa mala suerte. y si su nombre no

* Departamento de Idiomas, Facultad de Humanidades Universidad Autónoma de Santo Domingo, UASD.

** Cf. Miguel Collado, "De obras inéditas en la República Dominicana". "Coloquio", sábado 7 de julio de 1990, pág. 15 . 
aparece en los estudios sobre la novelística dominicana contemporánea, tampoco aparecen --o aparecen mal representados-- los nombres de Lacay Polanco, J.M. Sanz-Lajara, Haím H. López-Penha, etc.

Nuestro encuentro con las novelas de Colson ha sido de una manera completamente fortuita. Oímos hablar de él como pintor. En el salón de profesores de la Facultad de Humanidades de la Universidad Autónoma de Santo Domingo recuerdo que había, allí por los años ochenta, un óleo de él, "Refugio Antiaéreo". La obra, a pesar de la supuesta reputación del autor, tenía que aguantar todos los malos efectos de la intemperie, y no hablemos del continuo polvo que la cubría sin que nunca nadie tomara la iniciativa de sacudírselo de encima. Al conocer este lienzo, al ver reproducciones de otras obras en diferentes ocasiones, un día, mientras nos encontrábamos investigando en la Biblioteca central de esa institución, he ahí que nos topamos con dos novelas del maestro. Nos sorprendimos sobremanera. He aquí un pintor novelista nos dijimos, y, sin embargo, nadie le pone caso. Sentimos como resultado de esto, el deseo de rescatar a Colson del olvido y del descuido en que sus obras langGidecían. Sacamos fotocopia de ellas. Con el tiempo, hemos podido leer las dos novelas, se las cuales vamos a dar aquí, ahora, un breve reporte. Valga esto como contribución al conocimiento más amplio de Colson como escritor en un futuro no muy lejano.

Con lo presente no se quiere decir que Colson es un gran novelista. No lo es. Colson es más bien, diríamos, un dominicano que en un punto de su desarrollo como intelectual y como hombre decidió escribir novelas. Que esto es así nos lo dice él mismo en el prólogo de su primera novela, El maestro del vale. No hay que buscar en ella, escribe el autor, "bellezas literarias".

Esto no es, como pudiera pensarse, una figura retórica, un aparentar por su parte humilde frente a sus lectores; es, por el contrario, una observación sincera, en la cual el quiere revelarnos lo que es obvio:sus limitadas dotes de novelista. Después de todo, él es un pintor; y es como pintor, por lo que nos resulta, que siempre se presentó frente a la sociedad. En cuanto a esto, véase, por ejemplo, su Memorias de un pintor trashumante. París 1924|Santo Domingo 1968 (Santo Domingo: Fundación Colson, 1978). Ahí, en esas Memorias, Colson nunca nos menciona sus novelas. Es como si esas obras no existieran. Siendo amigo del poeta Tomás Hernández, del cual habla en extenso en el libro, sorprende el hecho de que callara tal cosa por completo. 
Como novelista Jaime Colson no tiene mucho que ofrecernos. Sin embargo, al leer las dos novelas publicadas, nos damos cuenta que se le hace una injusticia cuando se le olvida como tal. Hay muchos novelistas que se recuerdan y que, con nuestra sorpresa, publicaron novelas simplemente horrorosas. Colson no es, claro está, un Juan Bosch, un Prestol Castillo o un Lacay Polanco; pero tampoco es un Horacio Read, un Henríquez Castillo o un Miguel Alberto Román. Como novelista Colson está cerca, muy cerca de un Ligio Vizardi. Al igual que éste, tiene un determinado modo de escribir novelas. Le falta por completo la liricidad de Vizardi; pero tiene, como él, intereses filosóficos, los cuales se traducen en él en una clara preocupación social. De ahí, pues, el tipo de novelas que nos presenta. Ambas El maestro del vale (Ciudad Trujillo: Montalvo, 1951) y Las dos aldeas (ivi, 1954) son novelas preocupadas por el desarrollo de la sociedad dominicana, es decir, didácticas, como el título lo sugiere.

El didacticismo es el programa de Colson como novelista. En cuanto intelectual, en cuanto artista dominicano exilado en países lejanos de su tierra y, por consiguiente, conocedor de otras sociedades y costumbres, Colson sentía dentro de sí la necesidad de educar al pueblo dominicano, especialmente a la juventud de ese pueblo. Sus dos novelas tienen esos fines. Su "principal objeto", nos dice en el prólogo ya mencionado, es "corregir los grandes defectos que van labrando en aquel país [la República Dominicana], la desgracia de la juventud, haciendo peor la vejez, y más pobre a una nación que hoy debiera de estar a la vanguardia de todos los progresos humanos."

Ahora bien; ipor qué esto? ¿por qué su programa, su didacticismo? podemos entenderlo si consideramos, como ya hemos hecho, su condición de exilado y conocedor de otros pueblos y culturas; pero, además de esto, especialmente si miramos a las fechas de publicación de las dos novelas: 1951 y 1954. Estos son los años de oro de la dictadura trujillista. Como nos indica en las Memorias arriba citadas, Colson no tuvo mucho que ver con el régimen de Trujillo. Su vida se desarrolló casi por completo fuera de su país, entre Francia, España, México y Cuba. cuando regresó a Santo Domingo, fue para ocupar el cargo de Director de la Escuela de Bellas Artes, en el 1951. No duró mucho en su cargo. No tuvo contacto directo con el dictador. No era una personalidad-- y esto sale de las Memorias, como también de las dos novelas-- como para desenvolverse en el ambiente falso y asfixiante del Santo Domingo de 
la Era. En efecto, al dejar su cargo se refugió en Tamboril, la aldea en que vivía y en la cual vio morir a su amigo Tomás Hernández. Sin embargo, esto de estar lejos de la política de su país no significa un desinterés por lo que ocurre. Colson, ni en su diario vivir ni en sus novelas denuncia abiertamente la dictadura; Pero sabemos que era opuesto a ella, sabemos que consideraba al régimen dañino al desarrollo intelectual y moral del pueblo dominicano. Nada más lejos de la figura del tirano que los filósofos que en sus novelas nos presenta como guías tanto de los jóvenes como de la sociedad.

El didacticismo de estas dos novelas de colson se explica y se justifica. No es solo su manera de ser que le hace escribir novelas didácticas dirigidas a los jóvenes y a la sociedad dominicana de su tiempo. Es también, por reflejo, su oposición al régimen de Trujillo, oposición que no es --como quisiéramos-- espectacular, siguiendo, por ejemplo, las pautas de un Andrés Requena, sino callada, íntima, crepuscular y al mismo tiempo viril y visceral. En Colson tenemos al artista que no se prostituye. Tenemos, diríamos, al filósofo que sabe que inclinarse no significa romperse y que susurrar su protesta no quiere decir arrodillarse frente a los poderosos. "iEppur si muove!", insistía Galileo en similar situación.

¿Cómo se presenta este programa didáctico de Colson en sus dos novelas?

Basta con hojear tanto El maestro del vale como Las dos aldeas para darse cuenta de la presencia de ellas del programa didáctico del novelista. En ambas novelas hay una trama de que hablar ni situaciones interesantes que registrar. Todo lo que en ella ocurre se revuelve alrededor del personaje del maestro o del filósofo, don Juan Ciprián en la primera y Diógenes, en la segunda. En El maestro del vale, Ciprián, un viejo y rico hatero, imparte cátedras sobre el correcto vivir a un joven (Enrique Díaz) y a un campesino (el vale Benancio) que trabajan en su finca. En Las dos aldeas Diógenes hace lo mismo en la aldea de Doglaif y después más directamente al joven Julio en la aldea de Godlaif, en la cual tendrá que trasladarse para escapar a los abusos de los prepotentes de la primera aldea. Para Colson, Enrique Díaz y Julio quieren decir la juventud, esa juventud que necesita de una guía intelectual y moral; el vale Benancio y los aldeanos de Doglaif, por su lado, la sociedad dominicana que, en su triste atraso, necesita de esa misma guía. En cada novela, el maestro, es decir, el filósofo, muere a muy avanzada edad, 
pero no sin primero asegurarse de que sus enseñanzas tengan fruto en la juventud y en la sociedad. En El maestro del vale, Enrique y el vale son material y espiritualmente los herederos de don Juan Ciprián; en Las dos aldeas, lo es Ju!io, el cual, en tanto que periodista, indirectamente representa también al pueblo. Es obvio lo que Colson quiere significar con esto: la juventud y la sociedad dominicana tienen que escuchar y practicar las enseñanzas del maestro o del filósofo. ¿Por qué? Porque la juventud se desvía fácilmente del trabajo y de la moral y la sociedad, no poniéndole caso a estas cosas, se encuentra en un estado de caos y de degeneración, lo que hace imposible cualquier progreso en el país.

Es importante para Colson que la República Dominicana progrese. Los pueblos tienen que modernizarse. Ellos tienen que vivir. Son atrasados y mueren aquellos pueblos que se rehúsan a aceptar la luz de la razón y de la moral. El maestro del vale está ambientada en el 1948; Las dos aldeas entre 1900 y 1916. Las novelas, como sabemos, se publican en el 1951 y el 1954, respectivamente. ¿Por qué esta ambientación? Colson, cabe notar, nunca dice en sus novelas que la Era es un periódico de progreso, ni intelectual ni moral ni económico. Pues, ya que no lo dice, la ambientación le ellas, con la descripción de una sociedad caótica y atrasada en todos los sentidos, se refleja sobre esa misma Era. ¿Qué ha cambiado de 1948 a 1954? Muy poco. Trujillo no es un Juan Ciprián o un Diógenes y la sociedad de la Era, con su notoria falta de intelectualidad y moralidad, es prácticamente la misma de antes. Ahora, como entonces, se necesitan maestros y filósofos que, con sus buenas enseñanzas, sean guías verdaderos de la juventud y de la sociedad dominicana.

Es obvio que Colson, en tanto que novelista, no es un filósofo. Por eso, no tiene sentido tratar de extraer de sus novelas una "filosofia", un "sistema filosófico"propic. Después de todo, lo que le importa es dramatizar su mensaje: que la iuventud y la sociedad dominicana necesitan de una guía que ni tienen bijo el régimen de Trujillo ni han tenido en el pasado. Es una situación de caos y de atraso que hay que cambiar. Así, cuando él se pregunta ¿Cono?, la respuesta no es una "filosofía", sino una seric de observaciones que se aplican directamente al ambiente dominicano. y es este el elemento que hace sus novelas programáticas; el que las hace didácticas. 
Si miramos, pues, a El maestro del vale, nos encontramos con una larga serie de observaciones sobre las cuales Juan Ciprián, el maestro, cuenta por enderezar el camino de la juventud y de la sociedad: la pobreza, pero no la indigencia, es preferible a la riqueza mal habida; la importancia de la gratitud; el respeto por la naturaleza; el alejarse de las fiestas que tiendan a degenerar en riñas con muertos; su oposición a los apodos negativos, los cuales tienden a denigrar la persona, y a las : icas de gallos, al juego de las barajas, a la crueldad del campesino dominicano hacia los animales, al ron y el alcoholismo; la necesidad de evitar abogados y tribunales, ya que no ayudan al inocente;la importancia de la fe como consuelo y la negatividad de las supersticiones entre el pueblo; la denuncia de la falta de honor; la insinceridad del duelo en los velorios; el trato entre el joven y la muchacha que ama; la seriedad del matrimonio y de la familia; los negocios y como pueden tener éxito en el campo; el culto de la madre; los falsos amigos; la brujería y la haraganería; los chismes y las calumnias, etc. Tanto insiste Colson sobre estas observaciones que el capítulo XLIV consiste de una extensa lista de los que serían los consejos del maestro a Enrique Díaz (la juventud) y el vale Benancio (el pueblo) antes de morir, consejos que van de la importancia de la buena reputación a la economía como firme base de la riqueza al aseo y la decencia a la paciencia, la lotería, etc. y, como si esto no fuera bastante, en la Tercera Parte, Colson reproduce lo que sería el libro de don Prisciliano, amigo del maestro, La verdad en gotas y goticas, también una colección de consejos en forma de aforismos que abarcan todas las manifestaciones individuales y sociales.

Siendo esto así, nos preguntaríamos: ¿Qué dice Colson acerca de la política? Como hemos explicado arriba, Colson no se le enfrenta a la dictadura, y esto a pesar de sentirla ajena a su modo de ser y de vivir. Aquí y allá en la novela, irreparablemente, se le escapa alguna crítica ("Dirá alguno que no es la sociedad entera, sino parte, que apoya esta clase de diversiones; pero yo la confundiré toda; porque quien la apoya es quien tiene la dirección de la sociedad, y siendo cómplice la cabeza, lo es el cuerpo todo; la sociedad que se precia de culta; la sociedad que se respeta y que aspira a un puesto digno ante los ojos del mundo ilustrado, debe democráticamente elegir autoridades que sepan cumplir los deberes que impone la moral, o la religión; pues en donde se deja de respetar la moral, se camina hacia el retroceso,o la barbarie, que es la misma cosa.", pág. 38), pero la posición de Colson en relación al régimen de Trujillo es fundamentalmente la del cristiano frente a la 
tiranía, es decir, esa misma posición que él nos da al finalizar su novela, cuando, presentándonos la figura del Cristo, nos dice que hay que "dar al César lo que es del César y a Dios lo que es de Dios." (pág.285) Nosotros, en el presente, podríamos muy bien oponernos a esta actitud de colson y criticarla, pero no podemos negar que tiene y siempre ha tenido su función y que, a diferencia del novelista, no nos encontramos, al vivir, en la situación en que él y su generación se encontraron.

De ahí podemos entender que el trasfondo de ésta como de la otra novela de Colson es cristiano, y que todas su observaciones acerca de lo que la juventud y la sociedad dominicana tienen que hacer para asegurarse el progreso y la felicidad están relacionadas directamente a una posición moral cristiana.

Más dramático, más novelesco es el desarrollo de Las dos aldeas. Pero esta novela sufre de un esquematismo excesivo-- y esto por el énfasis que colson quiere darle a su programa didáctico. En efecto, en Las dos aldeas Colson nos presenta con el pueblo de Doglaif y el de Godlaif. Es su manera de decir que el hombre --el dominicano--puede y debe escoger entre una vida según los animales (Doglaif es la pronunciación en inglés "Doglife", es decir, "a dog's life", vida de perro)o una según Dios (Godlaif = "Godlife" = "God's life", vida del señor). Diógenes, el filósofo, vive en la primera aldea. Todos los vicios de la sociedad dominicana rigen la vida de la gente de esta aldea. Los ricos y los poderosos con sus hijos son como perros que ladran alrededor de la casa de Diógenes,el cual, con su linterna en mano, se esfuerza en buscar entre ellos un hombre honesto sin encontrarlo. Esta aldea, como también la segunda, sigue la ley del atavismo: los pecados o las virtudes de los padres pasarán a la vida de los hijos. De padres degenerados, nos dice Diógenes, pueden salir sólo hijos degenerados. Esto Colson nos lo prueba con el desarrollo de su novela. Está claro lo que ello quiere decir: con gente así no puede haber ni progreso ni felicidad en la sociedad. ¿Qué futuro puede el país tener con una juventud de "cachorros"entrenados por padres inmorales? Y Colson nos lo deja ver mostrándonos como la ley del atavismo golpea inexorablemente tres generaciones.

Tanto degeneran las cosas en Doglaif que Diógenes, para salvar su vida, tiene que tomar refugio en Godlaif. Allí todo es diferente. La misma ley se aplica; pero, ya que la gente es buena, al aplicarla la maldición no visita ni los padres ni sus hijos. Colson nos dice que no todo es perfecto en la aldea de Godlaif. Lo que ocurre es que en ella la 
gente buena impone su criterio sobre los demás. Por eso la aldea es centro económico y cultural. Por eso, en ella, un joven como Julio, que viene de las clases humildes, puede alcanzar el puesto social que anhela.

Es en esta otra aldea que el maestro Diógenes muere, rodeado de gente que lo ama y respeta, a los 85 años. Es en esta aldea donde se le reconocerá el valor que tenía como orientador de la juventud y de la sociedad. Es bajo su blanca estatua de mármol que los impenitentes doglaifianos que viven en Godlaif y estorban las cosas con sus crímenes e inmoralidades al final son apresados por la policía, y son llevados a su justo castigo. La juventud y la sociedad Dominicana, son la representación observada en esta otra novela de Colson. "El maestro Diógenes tuvo que emigrar de una vida de perros a una vida de Dios,"escribe Colson, mostrándonos así claramente la dinámica da su posición, "pero no resulta lo mismo con Julio. Este tenía el amor de un pueblo, cuya psicología se remontaba a un atavismo de pura sangre cristiana. Cada destello de aquel sol iba a iluminar unas almas sedientas de luz." (pág. 134).

He aquí, pues, las dos novelas didácticas del "maestro" Jaime Colson.

Colson, Jaime. EI maestro del vale. Ciudad Trujillo; Editora Montalvo, 1951.

---.. Las dos aldeas. ivi, 1954.

-...-. Memorias de un pintor trashumante. París 1924|Santo Domingo

1968. Santo Domingo: Fundación Colson, 1978

\section{PRESENTACION DEL LIBRO DESARROLLO HUMANO: INFORME 1991" \\ Eduardo Latorre $^{* *}$}

Agradecemos al Dr. César Miquel, Representante Residente del Programa de Desarrollo de las Naciones Unidas (PNUD) en la República Dominicana, la honrosa oportunidad de presentar a los dominica-

* 16 de septiembre de 1991.

** Director Ejecutivo Fundación Dominicana de Desarrollo (FDD) y ex-rector del INTEC. 